\title{
Cross Section Analysis of the KBW Nasdaq Financial Technology Index
}

\author{
Suresh Kadam ${ }^{1} \&$ Madhvi Sethi ${ }^{2}$ \\ ${ }^{1}$ Symbiosis International (Deemed University) (SIU), Lavale, Pune, India \\ ${ }^{2}$ Symbiosis Institute of Business Management (SIBM), Symbiosis International (Deemed University) (SIU), \\ Bengaluru, India
}

Correspondence: Suresh Kadam, H1105, MSR Queenstown Society, Udyognagar, Chinchwadgao, Pune 411033, Maharashtra, India. Tel: 91-91-6773-0873. E-mail:sureshkadam@ gmail.com

Received: February 12, 2020

Accepted: June 30, 2020

Online Published: October 5, 2020

doi:10.5430/ijfr.v11n5p450

URL: https://doi.org/10.5430/ijfr.v11n5p450

\begin{abstract}
Financial Technology (FinTech) has emerged as a potentially transformative force in the various financial segments. To track this new sector garnering investor attention, Keefe, Bruyette \& Woods and Nasdaq, came up with KBW Nasdaq Financial Technology Index (KFTX) on July 18, 2016 comprising of 49 constituents. The objective of this paper is to compare KFTX performance with the leading market indices, including S\&P 500 and Dow Jones Industrial Average index. The data is collected for a period of 12 months, 24 months and 34 months starting from July 18, 2016. The findings of the analysis suggest that the returns for KFTX are consistently higher for 12 months, 24 months and 34 months over S\&P 500 and Dow Jones Industrial Average. The cross section analysis of the 48 KFTX index constituents sub-classified into eight categories representing several different financial industry groups and businesses indicate that for the 34 months period networks and payments gave returns of $82.1 \%$ and $71.6 \%$ whereas asset management business gave an average negative return of $-51.0 \%$ and the specialty marketplace lenders gave a return of $26.6 \%$. This indicates a significant non-uniform growth within the FinTech industry. The findings motivate for an in-depth analysis of the various industry groups and businesses within the FinTech industry and to explore further the reasons and attributes which differentiate these sectors. The study has implications for policy makers, asset management companies and investors in terms of understanding and framing policies for FinTech investments.
\end{abstract}

Keywords: FinTech, KFTX, index return

\section{Introduction}

Technological innovation has resulted into a revolutionary change in financial services field. A large number of existing and new financial services entities and technology firms are experimenting with the technological innovations' and are modifying the way the financial intermediation takes place. This confluence of technology and financial services is broadly classified as Financial Technology or FinTech.

Technology is facilitating in unbundling of many services that have traditionally been offered by banks and financial conglomerates. FinTech has emerged as a potentially transformative force in the financial segments such as payments, asset management, financial data analysis, banking products, investment advisory, insurance etc. Some of the major FinTech products and services currently used in the market place are peer to peer lending platforms, crowd funding, block chain technology, distributed ledgers technology, Big Data, smart contracts, robo advisors, E-aggregators, etc. (RBI, 2017).

FinTech, though a new term, the influence of the technology on financial services dates back to advent of computer and internet. Several players have operated in this space and incorporated technology into their businesses to drive new products and services in financials for quite some time. However, such influence was less and restricted to back-end operations. But with the widespread of internet and mobile telephony services in the last couple of decades, the impact of technology has increased considerably. The technology innovation, process disruption and services transformation has led to FinTech revolution (Gomber, Kauffman, Parker, \& Weber, 2018). This has resulted into new set of FinTech companies which have caught up investor attention. Global investment in FinTech in 2018 is estimated to be $\$ 111.8$ billion (KPMG, 2019a). The disruptive nature of the FinTech has caught the attention of the regulators, who believe that it can have a large impact on the market structure (Financial Stability Board, 2019). 
To track this new sector garnering investor and regulator attention, Keefe, Bruyette \& Woods (KBW), an investment bank specialised in financial services and Nasdaq, an American stock exchange, came up with KBW Nasdaq Financial Technology Index (KFTX) to trace and keep pace with the acceleration and interest in FinTech through a single index of FinTech companies. KFTX is an equal-weighted index that tracks the performance of companies that leverage technology to deliver financial products and services (KBW, 2016a). Their distribution is nearly exclusively electronic, with limited or no "bricks and mortar," and their revenue mix is predominantly fee-based. KFTX started with an inception value of $\$ 1000$ on July 18, 2016 and 49 constituents sub-classified into eight categories representing several different financial industry groups and businesses namely payments, processors/business information, networks, financial data, internet banks, exchanges / automatic trading, software and specialty marketplace lenders. Index rebalance frequency is quarterly (KBW, 2016b). Currently there are 48 FinTech companies as part of the index.

In this study, the researcher's compare the performance of KFTX with S\&P 500 (INX), Dow Jones Industrial Average (DJI), NASDAQ Composite (IXIC) and S\&P Composite 1500 Financials (SPCOMF) over 12 months, 24 months and 34 months period from the inception of KFTX i.e. July 18, 2016. Further, the researchers analyse the cross section performance of the eight categories of KFTX components over 12 months, 24 months and 34 months period in an effort to understand whether the performance of eight categories under broad umbrella of FinTech are similar or divergent.

The findings indicate that the KFTX returns outperform all the major indices over 24 months and 34 months period. These findings complement the expectation that FinTech is garnering enormous investor attention because of its promise of the future. The performance is almost at same levels during the 12 months period for IXIC and SPCOMF and S\&P 500 and DJI.

The findings from the cross-section analysis of the KFTX bring out a different picture. Similar growth is not observed across various categories under the FinTech umbrella. asset management has shown negative return, whereas the performance of internet banks, specialty marketplace lenders and processor/business information companies is subdued. High returns are observed in networks and payments categories followed by performance of software, financial data and exchanges/automatic trading companies. These findings indicate that, FinTech being such a broad sector, it is imperative to understand the various categories under this broad sector to track and gauge the performance of FinTech. Consumer centric companies have fared well because of higher adoption of the technology and enhanced reach. New age companies providing asset management, loan products and lending market places seems to be still in the process of stabilising their business model from investor perspective.

These findings add to the literature in terms of the performance gauge for FinTech and necessity for focusing on various categories under FinTech. The findings motivate for an in-depth analysis of the various industry groups and businesses within the FinTech industry and to explore further the reasons and attributes which differentiate these sectors. The study has implications for policy makers, asset management companies and investors in terms of understanding and framing policies for FinTech investments.

This paper is organised into four sections. Section 2 provides details of data and methodology. Section 3 discusses the results and Section 4 concludes the paper.

\subsection{Objectives of the Study}

Researchers have following objectives:

1. To study the performance of the FinTech sector by observing the KBW Nasdaq Financial Technology Index and comparing it with other indices

2. To study the performance of various sub-sectors in FinTech by analysing the sub-classifications in the KBW Nasdaq Financial Technology Index

\section{Literature Review}

Bower and Christensen (1995) wrote about 'disruptive technologies' that had the potential to challenge the incumbent business. Over the decade since, the spread of internet and mobile technology had led to mushrooming of these disruptors. Post the financial crisis of 2008, there has been an overhaul in financial services sector and FinTech has emerged as the most disruptive innovation in the finance field.

FinTech has been broadly classified in three era's; FinTech 1.0, from around 1866 to 1967, where technology was heavily interlinked with financial services industry, but remained largely an analogue industry; FinTech 2.0, from around 1967 to 2008, saw digitisation of the financial services dominated by the traditional regulated financial 
services industry; FinTech 3.0, since 2008, experiencing the democratization of the financial services where technology companies and new start-ups deliver financial services directly to business and general public (Arner, Barberis, \& Buckley, 2015)

During the past few years various attempts have been made to map this post-crisis FinTech era. Pollari (2016) identified seven primary drivers for FinTech namely (a) changing consumer behaviour and preferences, (b) digital and mobile devices, (c) accelerating pace of technology change, (d) declining levels of trust, (e) barriers of entry for digital disruptors falling, (f) attractive profit pools which are accessible and (g) supporting policy and regulatory environment. Lee and Shin (2018) studied the FinTech ecosystem and identified six FinTech business models namely payment, wealth management, crowd-funding, lending, capital market and insurance. Gozman, Liebenau, \& Mangan (2018) clustered the innovation mechanism of the FinTech start-ups into those providing services, business infrastructure and components. Gomber et al (2018) mapped the innovation in FinTech in financial services to four key areas namely operations management, payments \& settlements, lending \& deposits and investments and noted that dominance of the long standing leading firms that are not able to adapt is at stake. Several efforts have been made to provide coherence and develop the understanding about the global FinTech landscape.

Blockchain is considered another disruptive core technology having its application in distributed storage, peer-to-peer networking, cryptography, smart contracts etc (Xu, Chen, \& Kou, 2019). Bailey (2016) analysed the Fintech disruption in capital market space and noted that forces of disruption will lead to a new version of the capital market for tomorrow.

The growth of FinTech has led to greater accessibility of financial services; Zhang, Tan, Hu, Wang, \& Wan (2020) noted that in China FinTech has been contributing to urbanization in spite of digital divide and lack of internet access and generating jobs and raising income in non-agricultural sectors. Jagtiani \& Lemieux (2018) noted that in addition to being competitive in concentrated banking markets, FinTech provided credit assess to areas underserved by the traditional banks. Thus, instead of competing, cooperation with FinTech companies is a prominent option for banks, which can lead to innovation lacking in the traditional banking sector (Drasch, Schweizer, \& Urbach, 2018).

Dranev, Frolova \& Ochirova (2019) analysed the impact of FinTech on stock returns and have documented significant positive average abnormal return after acquisition of FinTech companies in the short-term and negative average abnormal return in the long-term. Lee and Shin (2018) suggested real options approach to value FinTech companies as against traditional NPV approach.

As per the FinTech Adoption Index published by EY, adoption of FinTech services has moved from 16\% in 2015 to 64\% in 2019; worldwide, 96\% of consumers know of at least one alternative FinTech service available to help them transfer money and make payments (EY, 2019). FinTech has caught the investor attention as well, with FinTech deals in M\&A reaching \$97.53 billion in first five months on 2019 (S\&P Global Market Intelligence).

As per Financial Stability Board (2019), FinTech offers products potentially challenge the traditional business models and will have implications for financial stability and warrant vigilance by supervisors. RBI (2017) has identified that the regulators action may vary from 'disclosure' to 'light-touch regulation \& supervision' to a 'tight regulation and full-fledged supervision' based on the risk implications. Pollari (2016) notes that large multinational giants may pose a bigger threat of disruption given their strong user base, access to data and low-cost operations. Anagnostopoulos (2018) notes that disruptive innovation can have positive outcomes for consumers, gains for regulators and reputational gains for financial services industry. Financial sector regulators now believe that greater engagement with FinTech entities is a necessity in response to the changing environment.

It is clear that FinTech is no more a hype but a major factor in the financial world. Although large body of the research exist on the FinTech ecosystem, technologies and impact analysis of their disruptive nature on the various financial services, limited research is undertaken to understand the performance of the FinTech companies from the investor point of view. The limited research in this field may be due to nascent stage of some of the technology firms.

FinTech is the new emerging sector that interests fund managers. It is drawing large investments. Global FinTech investment stood at $\$ 37.9$ billion across 962 deals in first half of 2019 (KPMG, 2019b). So this paper attempts to bridge this research gap in understanding of the performance of the FinTech companies.

Historically, sectorial indices have been used as a proxy to gauge the performance of the sector (Horrigan, Case, Geltner, \& Pollakowski, 2009). Researchers, through this paper, have attempted to bridge this gap in literature by analysing KFTX index which tracks the FinTech sector. Further, FinTech being a broad sector, analysis of the index components is conducted to represent better the performance of the sector (Feeney \& Hester, 1964). 


\section{Data}

KBW Nasdaq Financial Technology Index is designed by Keefe, Bruyette \& Woods and Nasdaq to track the performance of financial technology companies that are publicly traded in the U.S. It is an equal weighted index started on July 18, 2016 with 49 component companies with quarterly rebalances. During inception the 49 components were divided into 8 sub-classifications. Out of the 49 companies, only 41 companies are the components of the KFTX during the period of the study i.e. May 2019. Previous seven companies have been removed from the index failing to meet the continued eligibility criteria as specified by the managers of the index, one company was acquired and the holding company is now part of the index. New six companies were added to the index during the period from July 2016 to May 2019 meeting the eligibility criteria.

The researchers have analysed the 48 component companies of KFTX as on May 2019. The brief details of the sub-classifications are specified in Table 1 and the additional details of the companies are placed in Appendix A. The sub-classification for 41 original companies is maintained as is, for the balance 7 companies the sub-classifications is determined on the best compatibility basis. The researchers have added an additional sub-classification of Asset Management.

Table 1. Brief details of KFTX component companies

\begin{tabular}{|c|c|c|c|}
\hline Sub-classification & No. of & \multicolumn{2}{|c|}{ Company Names } \\
\hline $\begin{array}{l}\text { Asset Management } \\
\text { Exchanges / Automatic } \\
\text { Trading }\end{array}$ & $\begin{array}{l}1 \\
6\end{array}$ & $\begin{array}{l}\text { - WisdomTree Investments, Inc } \\
\text { - CBOE Holdings, Inc. } \\
\text { - CME Group, Inc. } \\
\text { - Intercontinental Exchange, Inc. }\end{array}$ & $\begin{array}{l}\text { - MarketAxess Holdings, Inc. } \\
\text { - Nasdaq, Inc. } \\
\text { - Virtu Financial, Inc. }\end{array}$ \\
\hline Financial Data & 9 & $\begin{array}{l}\text { - Equifax, Inc. } \\
\text { - FactSet Research Systems Inc. } \\
\text { - Fair Isaac Corp. } \\
\text { - IHS Markit Ltd. } \\
\text { - Moody's Corp. }\end{array}$ & $\begin{array}{l}\text { - MSCI, Inc. } \\
\text { - S\&P Global, Inc. } \\
\text { - Thomson Reuters Corp. } \\
\text { - Transunion }\end{array}$ \\
\hline Internet Banks & 1 & - Axos Financial, Inc. & \\
\hline Networks & 3 & $\begin{array}{l}\text { - American Express Co. } \\
\text { - MasterCard, Inc. }\end{array}$ & - Visa, Inc. \\
\hline Payments & 12 & $\begin{array}{l}\text { - ACI Worldwide, Inc. } \\
\text { - Evertec, Inc. } \\
\text { - Fidelity National Information } \\
\text { Services, } \\
\text { - FleetCor Technologies, Inc. } \\
\text { - Green Dot Corp. } \\
\text { - Global Payments, Inc. }\end{array}$ & $\begin{array}{l}\text { - PayPal Holdings, Inc. } \\
\text { - Square, Inc. } \\
\text { - Total System Services, Inc. } \\
\text { - Wex, Inc. } \\
\text { - Worldpay, Inc. } \\
\text { - The Western Union Co. }\end{array}$ \\
\hline $\begin{array}{l}\text { Processors / Business } \\
\text { Information }\end{array}$ & 12 & $\begin{array}{l}\text { - Alliance Data Systems Corp. } \\
\text { - Black Knight Financial } \\
\text { Services, Inc. } \\
\text { - Broadridge Financial Solutions, } \\
\text { Inc. } \\
\text { - Cardtronics, Inc. } \\
\text { - CoreLogic, Inc. } \\
\text { - Costar Group Inc } \\
\text { - Euronet Worldwide, Inc. }\end{array}$ & $\begin{array}{l}\text { - Fiserv, Inc. } \\
\text { - Jack Henry \& Associates, } \\
\text { Inc. } \\
\text { - SEI Investments Co. } \\
\text { - SS\&C Technologies } \\
\text { Holdings, Inc. } \\
\text { - Verisk Analytics, Inc. }\end{array}$ \\
\hline Software & 1 & - Envestnet, Inc & \\
\hline $\begin{array}{l}\text { Specialty Marketplace } \\
\text { Lenders }\end{array}$ & 3 & $\begin{array}{l}\text { - LendingClub Corp. } \\
\text { - On Deck Capital, Inc. }\end{array}$ & - Lendingtree, Inc. \\
\hline
\end{tabular}


For the period from July 18, 2016 to May 20, 2019, the closing price data for the indices namely KFTX, S\&P 500, DJI, IXIC and SPCOMF was considered; adjusted closing price data was considered for the 48 component companies. The data was downloaded from yahoo finance and investing.com.

The US Treasury bill yield for the period 1 year, 2 year and 3 year as on July 18, 2016 was downloaded from investing.com.

\section{Methodology, Tools and Techniques}

To analyse the data, log returns are computed for 5 indices and 48 component companies for the 12 months, 24 months and 34 months periods starting July 18, 2016 (inception date of the KFTX index).

Beta values are computed for each component companies as a measure of risk for the corresponding period by dividing covariance of the stock return and market returns by the variance of the market returns (Fama \& French, 2004). S\&P Composite 1500 is used as the market portfolio.

To analyse the cross sectional performance of the KFTX index, the index was divided into nine small portfolios (P1, P2, P3 etc) as per the sub-classifications. Returns of the portfolios for the 12 month, 24 month and 34 month period for sub-classifications are the arithmetic mean of the sub-classifications components returns for the said period. Beta values of the portfolios are the arithmetic mean of the sub-classifications component betas for the said period considering equal weighted portfolio.

Treynor ratio is computed for each portfolio to measure the market risk adjusted returns of the portfolios.

$$
T=\frac{r_{i}-r_{f}}{\beta_{i}}
$$

Where, $r_{i}$ is the portfolio i's return, $r_{f}$ is the risk free rate (US treasury bill rates of the corresponding period have been considered) and $\beta$ is the portfolio i's beta.

Terynor ratio is the reward-to-risk ratio that is used to standardize the excess return of the portfolio by using their respective betas (Hsieh \& Hodnett, 2013), higher the ratio, superior the performance of the portfolio.

\section{Results}

At first the comparison of the performance of the KFTX index with the leading indices followed by the cross section analysis of the index components is done.

\section{a. Key Indices}

The performance of the KFTX index over the 24 months and 34 months period is very superior as compared to all the major indices such as S\&P 500, Dow Jones Industrial Average, Nasdaq Composite and S\&P Composite 1500 Financials (see Table 2. Comparison of KFTX performance with major indices). KFTX return for 34 months is $20 \%$ higher than S\&P 500. The returns for KFTX are consistently higher for 12 months, 24 months and 34 months over S\&P 500 and Dow Jones Industrial Average. KFTX has 57.2\% returns for 34 months as against $42.1 \%$ and 32.5\% returns of NASDAQ Composite and S\&P Composite 15000 Financials. At inception KFTX had 10-year historical average beta of 1.02. Therefore, higher returns in the KFTX can be attributed to superior performance of FinTech companies and/or investor anticipation of exceptional performance by the FinTech companies in upcoming years.

Table 2. Comparison of KFTX performance with major indices

\begin{tabular}{llrrr}
\hline Ticker & Index/Company Name & \multicolumn{3}{c}{ Returns $^{\mathbf{1}}$} \\
\cline { 3 - 5 } & & 12 months & 24 months & 34 months \\
\hline KFTX & KBW Nasdaq Financial Technology & $21.6 \%$ & $50.4 \%$ & $57.2 \%$ \\
INX & S\&P 500 & $12.7 \%$ & $26.2 \%$ & $27.1 \%$ \\
DJI & Dow Jones Industrial Average & $15.2 \%$ & $30.7 \%$ & $32.6 \%$ \\
IXIC & NASDAQ Composite & $22.7 \%$ & $44.1 \%$ & $42.1 \%$ \\
SPCOMF & S\&P Composite 1500 Financials & $24.8 \%$ & $36.8 \%$ & $32.5 \%$ \\
\hline
\end{tabular}

1. Log returns for 12 months is July 18, 2016 to July 18, 2017; for 24 months is July 18, 2016 to July 18, 2018; for 34 months is July 18, 2016 to May 20, 2019 


\section{b. KFTX Index Sub-Classifications}

To study the performance of the various FinTech sub-sectors, the sub-classification analysis of the KFTX is done using the Treynor ratio. The sub-classifications of the KFTX as per the sectors were analysed as portfolios. The returns, beta and treynor ratio computed for the 12, 24 and 34 month period are provided in Table 3 . Table 3 is arranged in the descending order of 34 month portfolio treynor ratio.

Exchanges/automatic trading has highest treynor ratio indicating maximum excess return per unit of risk (see Table 3). The performance of networks, payments and financial data firms is also superior. However, asset management has negative treynor ratio and ratio for processors/business information and specialty market lenders is low. This indicates that consumer centric companies have fared well because of higher adoption of the technology and enhanced reach, whereas, new age companies seems to be still in the process of stabilising their business model.

Table 3. Analysis of the sub-classifications of KFTX

\begin{tabular}{|c|c|c|c|c|c|}
\hline Portfolio & Index Sub-Classifications & & 12 months & 24 months & 34 months \\
\hline \multirow{3}{*}{ P1 } & \multirow{3}{*}{ Exchanges / Automatic Trading } & $R^{l}$ & $18.90 \%$ & $46.00 \%$ & $52.90 \%$ \\
\hline & & $\beta^{2}$ & 0.82 & 0.62 & 0.52 \\
\hline & & $T^{3}$ & 0.22 & 0.73 & 1.01 \\
\hline \multirow{3}{*}{$\mathrm{P} 2$} & \multirow{3}{*}{ Networks } & & $30.00 \%$ & $65.20 \%$ & $82.10 \%$ \\
\hline & & & 1.06 & 1.1 & 1.17 \\
\hline & & & 0.28 & 0.59 & 0.70 \\
\hline \multirow{3}{*}{ P3 } & \multirow{3}{*}{ Payments } & & $24.50 \%$ & $63.10 \%$ & $71.60 \%$ \\
\hline & & & 1.17 & 1.08 & 1.2 \\
\hline & & & 0.20 & 0.58 & 0.59 \\
\hline \multirow{3}{*}{ P4 } & \multirow{3}{*}{ Financial Data } & & $17.80 \%$ & $44.40 \%$ & $58.60 \%$ \\
\hline & & & 1.03 & 0.93 & 0.99 \\
\hline & & & 0.17 & 0.47 & 0.59 \\
\hline \multirow{3}{*}{ P5 } & \multirow{3}{*}{ Internet Banks } & & $38.70 \%$ & $90.40 \%$ & $56.60 \%$ \\
\hline & & & 1.98 & 1.38 & 1.22 \\
\hline & & & 0.19 & 0.65 & 0.46 \\
\hline \multirow{3}{*}{ P6 } & \multirow{3}{*}{ Software } & & $4.30 \%$ & $45.40 \%$ & $59.30 \%$ \\
\hline & & & 1.69 & 1.2 & 1.28 \\
\hline & & & 0.02 & 0.37 & 0.46 \\
\hline \multirow{3}{*}{ P7 } & \multirow{3}{*}{ Processors/Business Information } & & $11.60 \%$ & $30.70 \%$ & $34.60 \%$ \\
\hline & & & 0.99 & 0.95 & 1.03 \\
\hline & & & 0.11 & 0.32 & 0.33 \\
\hline \multirow{3}{*}{ P8 } & \multirow{3}{*}{ Specialty Marketplace Lenders } & & $16.60 \%$ & $40.60 \%$ & $26.60 \%$ \\
\hline & & & 1.86 & 1.23 & 1.32 \\
\hline & & & 0.09 & 0.33 & 0.20 \\
\hline \multirow{3}{*}{ P9 } & \multirow{3}{*}{ Asset Management } & & $-7.70 \%$ & $-17.40 \%$ & $-51.00 \%$ \\
\hline & & & 1.92 & 1.6 & 1.42 \\
\hline & & & -0.04 & -0.11 & -0.36 \\
\hline
\end{tabular}

1. Log returns for 12 months is July 18, 2016 to July 18, 2017; for 24 months is July 18, 2016 to July 18 , 2018; for 34 months is July 18, 2016 to May 20, 2019

2. Beta values of the sub-classification are the arithmetic mean of the sub-classifications component betas for the said period considering equal weighted portfolio

3. Treynor ratio of the sub-classification computed using US treasury yields of $0.520 \%, 0.690 \%$ and $0.846 \%$ for 1 year, 2 year and 3 year respectively 
In the following sections, performance of the individual sub-classification is analysed.

\section{c. Asset Management}

The returns over the three time periods and the corresponding $\beta$ values are presented in the Table 4 . It is observed that asset management component of the KFTX has given negative returns across all the three time periods and has a very high beta. Figure 1 represents the cumulative returns of asset management components alongside the S\&P Composite 15000 cumulative returns over the period from July 18, 2016 to May 20, 2019.

Table 4. Analysis of asset management sub-classification

\begin{tabular}{|c|c|c|c|c|}
\hline \multirow{2}{*}{ Ticker } & \multirow[t]{2}{*}{ Component/Company Name } & \multicolumn{3}{|c|}{ Returns $^{1}$} \\
\hline & & 12 months & 24 months & 34 months \\
\hline \multicolumn{2}{|c|}{ Asset Management } & $\begin{array}{l}-7.7 \% \\
(1.92)^{4}\end{array}$ & $\begin{array}{r}-17.4 \% \\
(1.60)\end{array}$ & $\begin{array}{r}-51.0 \% \\
(1.42)\end{array}$ \\
\hline WETF & WisdomTree Investments, Inc & $\begin{array}{l}-7.7 \% \\
(1.92)^{3}\end{array}$ & $\begin{array}{r}-17.4 \% \\
(1.60)\end{array}$ & $\begin{array}{r}-51.0 \% \\
(1.42)\end{array}$ \\
\hline
\end{tabular}

1. Log returns for 12 months is July 18, 2016 to July 18, 2017; for 24 months is July 18, 2016 to July 18 , 2018; for 34 months is July 18, 2016 to May 20, 2019

2. Returns for sub-classifications are the arithmetic mean of the sub-classifications components returns for the said period.

3. Figures in the brackets are the beta values computed for the corresponding period with S\&P Composite 1500 as market portfolio.

4. Beta values of the sub-classification are the arithmetic mean of the sub-classifications component betas for the said period considering equal weighted portfolio.
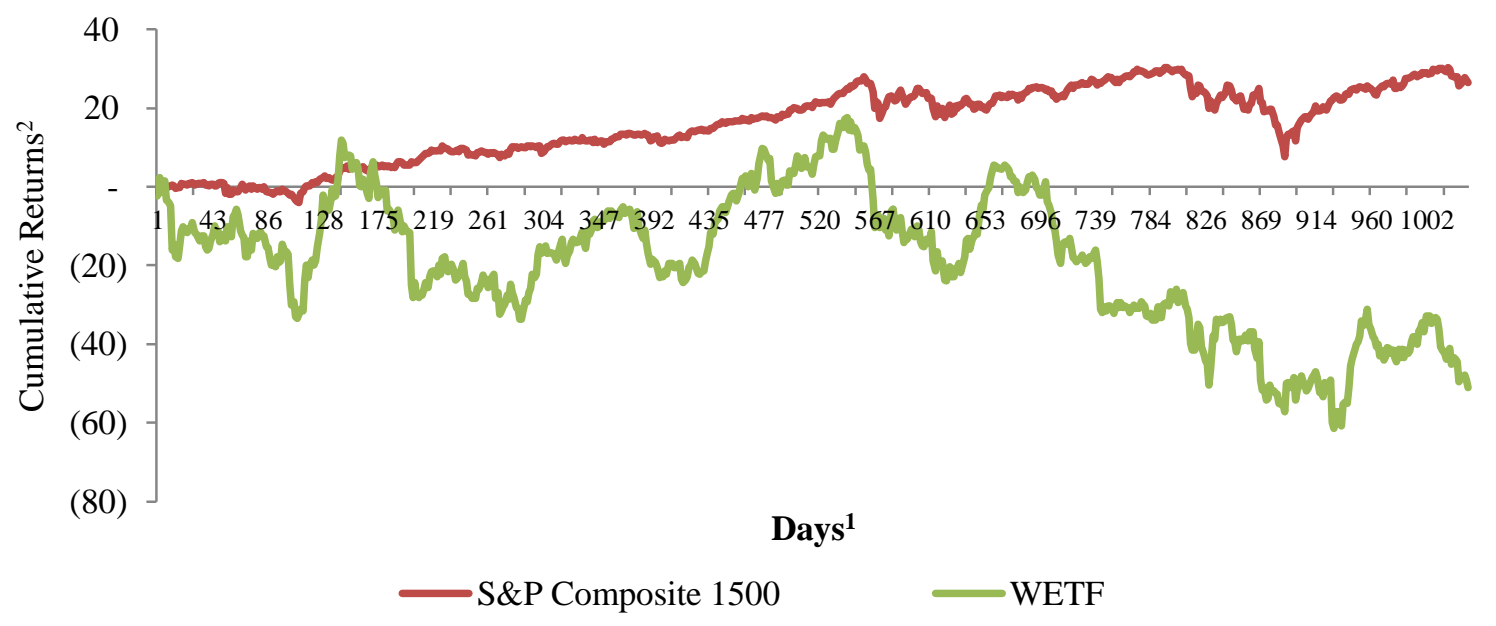

Figure 1. Cumulative returns of asset management sub-classification companies

1. Axis represents the days starting with Day 0 as July 18, 2016 till May 20, 2019

2. Cumulative returns are the summation of the daily log returns over the specified number of the days starting July 18, 2016

\section{d. Exchanges / Automatic Trading}

The performance of the exchanges/automatic trading companies is superior to KFTX and other indices over the 24 month and 34 month period at a lower risk compared to the market portfolio indicating better performance of the FinTech companies in this sector. 
Table 5. Analysis of exchanges/automatic trading sub-classification

\begin{tabular}{llrrr}
\hline \multirow{2}{*}{ Ticker } & Component/Company Name & \multicolumn{3}{c}{ Returns } \\
\cline { 3 - 5 } & & 12 months & 24 months & 34 months \\
\hline \multirow{2}{*}{ Exchanges } & & $18.9 \%$ & $46.0 \%$ & $52.9 \%$ \\
& & $(0.82)$ & $(0.62)$ & $(0.52)$ \\
CBOE & CBOE Holdings, Inc. & $32.5 \%$ & $46.5 \%$ & $48.9 \%$ \\
& & $(0.62)$ & $(0.60)$ & $(0.48)$ \\
CME & \multirow{2}{*}{ CME Group, Inc. } & $22.1 \%$ & $61.2 \%$ & $71.6 \%$ \\
& & $(0.94)$ & $(0.94)$ & $(0.64)$ \\
ICE & \multirow{2}{*}{ Intercontinental Exchange, Inc. } & $25.0 \%$ & $42.4 \%$ & $48.9 \%$ \\
& & $(0.78)$ & $(0.91)$ & $(0.76)$ \\
MKTX & \multirow{2}{*}{ MarketAxess Holdings, Inc. } & $25.7 \%$ & $35.0 \%$ & $69.5 \%$ \\
\multirow{2}{*}{ NDAQ } & \multirow{2}{*}{ Nasdaq, Inc. } & $(1.19)$ & $(0.68)$ & $(0.49)$ \\
& & $7.8 \%$ & $38.5 \%$ & $34.2 \%$ \\
VIRT & \multirow{2}{*}{ Virtu Financial, Inc. } & $(0.72)$ & $(0.77)$ & $(0.77)$ \\
& & $0.1 \%$ & $52.7 \%$ & $44.6 \%$ \\
\end{tabular}

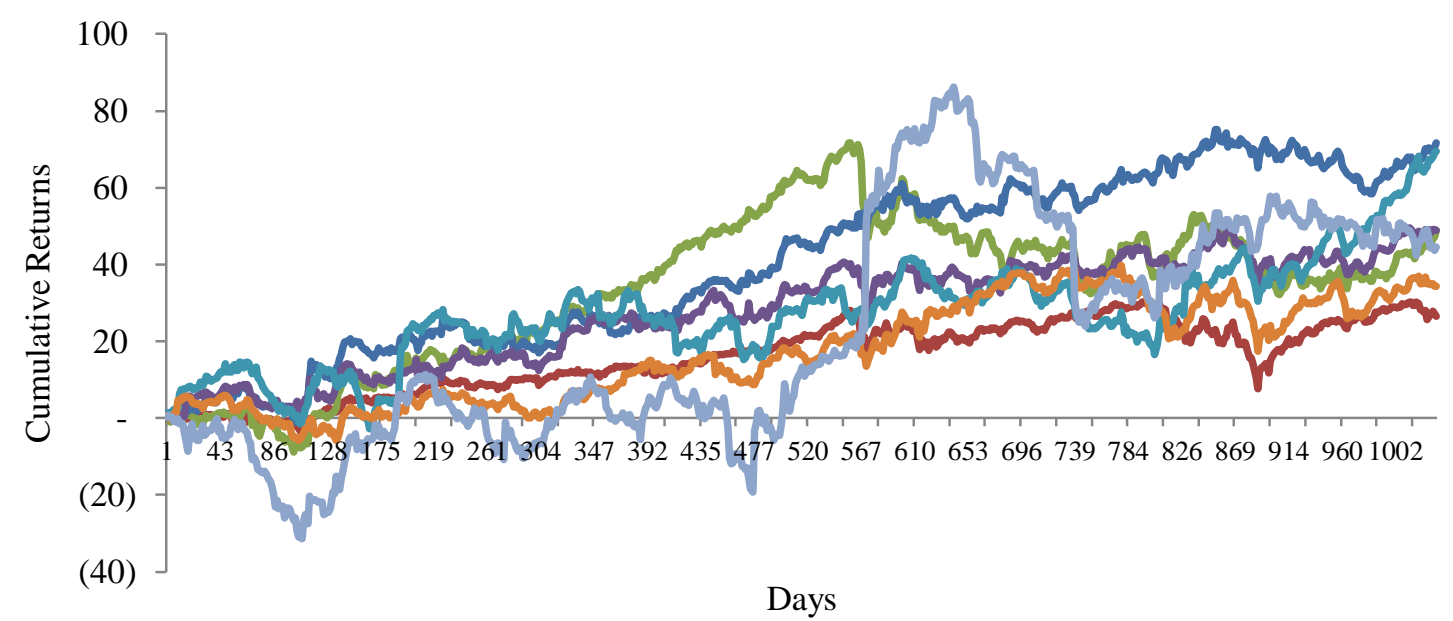

$\longrightarrow$ S\&P Composite $1500 \longrightarrow$ CBOE $\longrightarrow$ CME $\longrightarrow$ ICE $\longrightarrow$ MKTX $\longrightarrow$ NDAQ $\longrightarrow$ VIRT

Figure 2. Cumulative returns of exchanges/automatic trading sub-classification companies

\section{e. Financial Data}

The performance of the financial data companies is superior to KFTX and other indices over the 24 month and 34 month period at a risk comparable to the market portfolio indicating better performance of the FinTech companies in this sector.

Table 6. Analysis of financial data sub-classification

\begin{tabular}{lrrr}
\hline Ticker Component/Company Name & \multicolumn{3}{c}{ Returns } \\
\cline { 2 - 4 } & 12 months & 24 months & 34 months \\
\hline Financial Data & $17.8 \%$ & $44.4 \%$ & $58.6 \%$ \\
& $(1.03)$ & $(0.93)$ & $(0.99)$ \\
\hline
\end{tabular}




\begin{tabular}{|c|c|c|c|c|}
\hline EFX & Equifax, Inc. & $\begin{array}{r}6.6 \% \\
(0.95)\end{array}$ & $\begin{array}{c}-3.5 \% \\
(0.83)\end{array}$ & $\begin{array}{l}-6.5 \% \\
(0.77)\end{array}$ \\
\hline FDS & FactSet Research Systems Inc. & $-1.5 \%$ & $23.8 \%$ & $54.0 \%$ \\
\hline FICO & Fair Isaac Corp. & $\begin{array}{r}(0.91) \\
19.6 \%\end{array}$ & $\begin{array}{l}(0.87) \\
57.2 \%\end{array}$ & $\begin{array}{r}(0.91) \\
91.4 \%\end{array}$ \\
\hline INFO & IHS Markit Ltd. & $\begin{array}{r}25.4 \% \\
(0.79)\end{array}$ & $\begin{array}{r}41.0 \% \\
(0.79)\end{array}$ & $\begin{array}{r}49.1 \% \\
(0.91)\end{array}$ \\
\hline MCO & Moody's Corp. & $\begin{array}{r}20.9 \% \\
(1.07)\end{array}$ & $\begin{array}{c}60.2 \% \\
(1.10)\end{array}$ & $\begin{array}{c}61.5 \% \\
(1.17)\end{array}$ \\
\hline MSCI & MSCI, Inc. & $\begin{array}{r}28.9 \% \\
(1.19)\end{array}$ & $\begin{array}{c}77.2 \% \\
(1.06)\end{array}$ & $\begin{array}{r}104.6 \% \\
(1.19)\end{array}$ \\
\hline SPGI & S\&P Global, Inc. & $\begin{array}{c}26.1 \% \\
(1.05)\end{array}$ & $\begin{array}{c}62.9 \% \\
(1.11)\end{array}$ & $\begin{array}{c}62.5 \% \\
(1.07)\end{array}$ \\
\hline TRI & Thomson Reuters Corp. & $\begin{array}{r}9.4 \% \\
(0.72)\end{array}$ & $\begin{array}{r}3.9 \% \\
(0.53)\end{array}$ & $\begin{array}{r}48.9 \% \\
(0.50)\end{array}$ \\
\hline TRU & Transunion & $\begin{array}{r}25.2 \% \\
(1.17) \\
\end{array}$ & $\begin{array}{r}76.5 \% \\
(0.94)\end{array}$ & $\begin{array}{r}61.7 \% \\
(1.10) \\
\end{array}$ \\
\hline
\end{tabular}

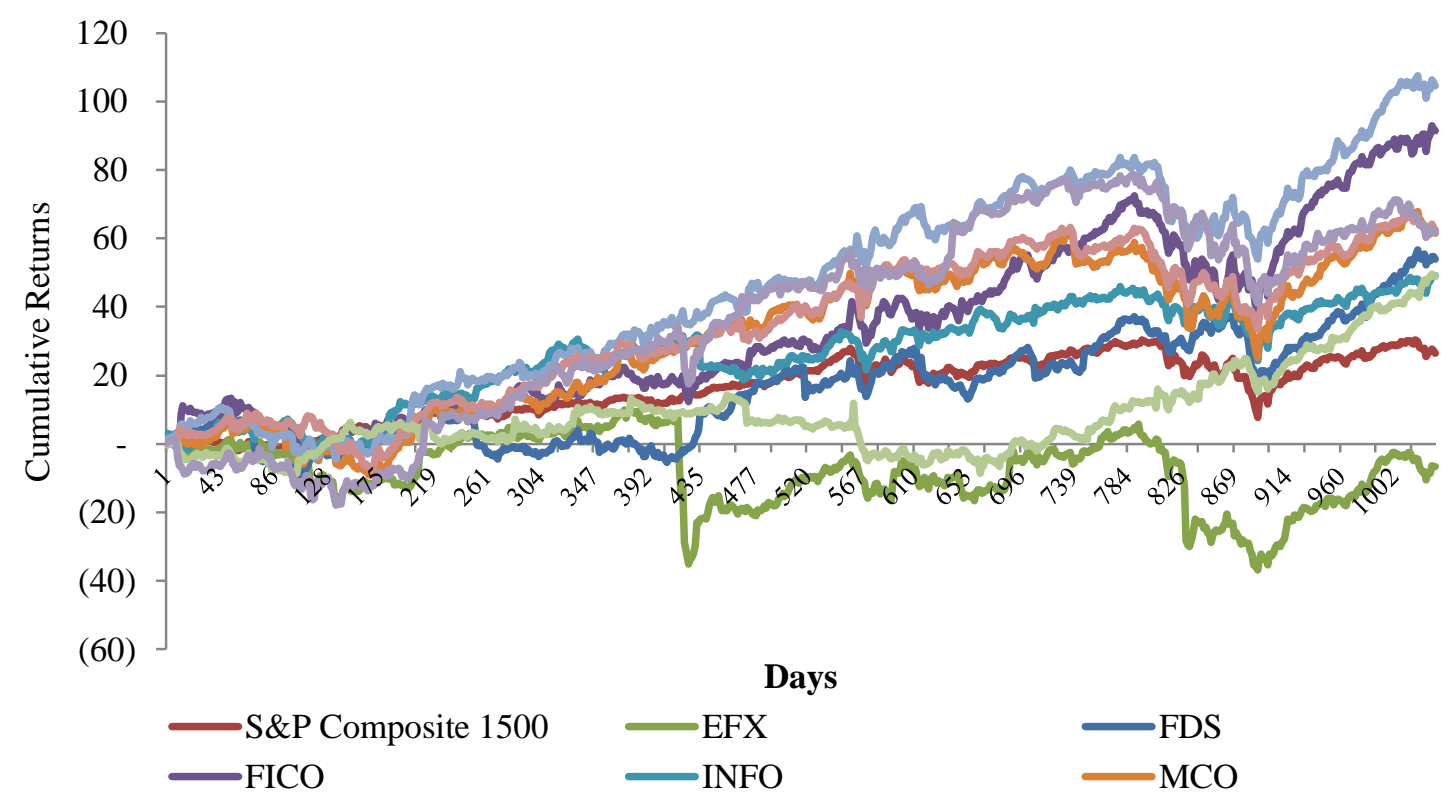

Figure 3. Cumulative returns of financial data sub-classification companies

\section{f. Internet Banks}

The performance of the internet bank companies is superior to KFTX and other indices over all the three time period. However the beta values of the firm are high indicating considerable risk.

Table 7. Analysis of internet banks sub-classification

\begin{tabular}{|c|c|c|c|c|}
\hline \multirow[t]{2}{*}{ Ticker } & \multirow{2}{*}{ Component/Company Name } & \multicolumn{3}{|c|}{ Returns } \\
\hline & & 12 months & 24 months & 34 months \\
\hline \multicolumn{2}{|c|}{ Internet Banks } & $38.7 \%$ & $90.4 \%$ & $56.6 \%$ \\
\hline $\mathbf{A X}$ & Axos Financial, Inc. & $\begin{array}{r}(1.98) \\
38.7 \% \\
(1.98)\end{array}$ & $\begin{array}{r}(1.38) \\
90.4 \% \\
(1.38)\end{array}$ & $\begin{array}{c}(1.22) \\
56.6 \% \\
(1.22)\end{array}$ \\
\hline
\end{tabular}




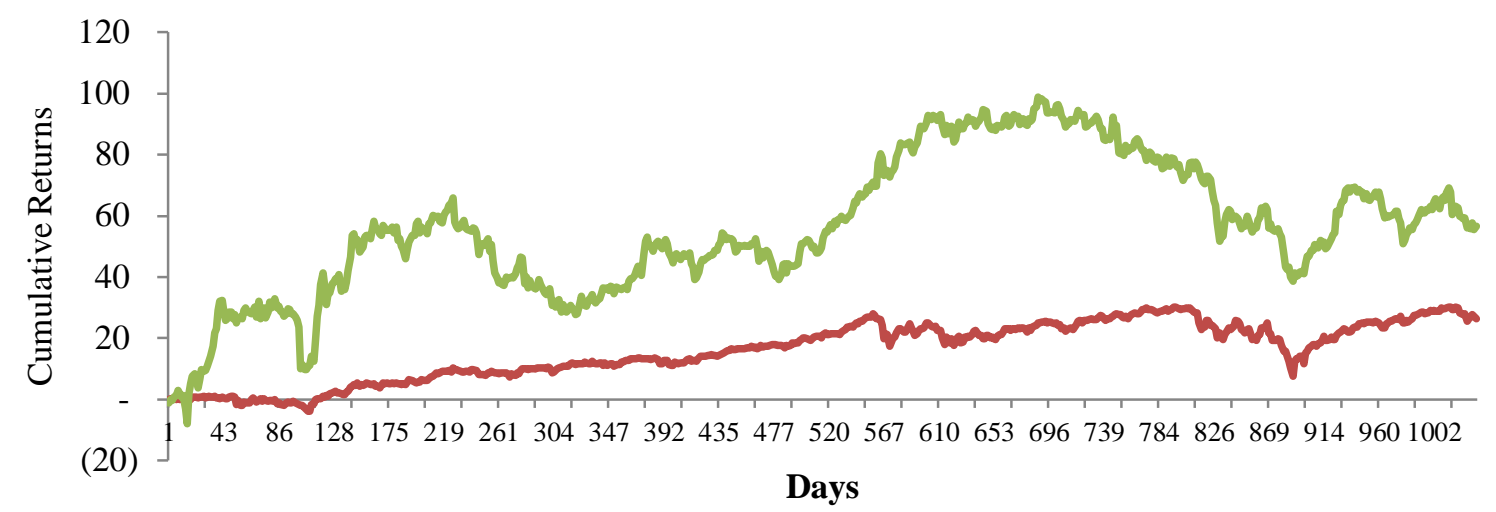

S\&P Composite $1500 \quad$ AX

Figure 4. Cumulative returns of internet bank sub-classification companies

\section{g. Networks}

The performance of the networks companies is superior to KFTX and other indices over all the three time period at a slightly higher risk comparable to the market portfolio indicating better performance of the FinTech companies in this sector. Networks have produced highest returns among all sub-classifications of the KFTX component companies.

Table 8. Analysis of networks sub-classification

\begin{tabular}{llrrr}
\hline Ticker & Component/Company Name & \multicolumn{3}{c}{ Returns } \\
\cline { 3 - 5 } & & 12 months & 24 months & 34 months \\
\hline Networks & & $30.0 \%$ & $65.2 \%$ & $82.1 \%$ \\
\multirow{2}{*}{ AXP } & \multirow{2}{*}{ American Express Co. } & $(1.06)$ & $(1.10)$ & $(1.17)$ \\
& & $33.3 \%$ & $51.9 \%$ & $67.0 \%$ \\
MA & MasterCard, Inc. & $(1.11)$ & $(1.09)$ & $(1.05)$ \\
& & $34.0 \%$ & $83.5 \%$ & $103.6 \%$ \\
V & Visa, Inc. & $(1.06)$ & $(1.12)$ & $(1.28)$ \\
& & $22.8 \%$ & $60.2 \%$ & $75.7 \%$ \\
& & $(1.00)$ & $(1.10)$ & $(1.18)$ \\
\hline
\end{tabular}

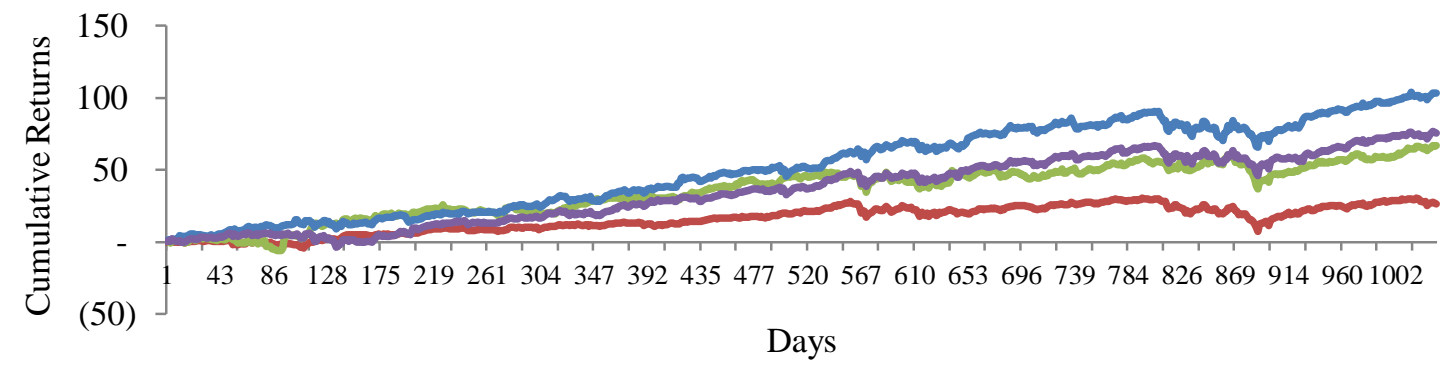

$\longrightarrow$ S\&P Composite $1500 \longrightarrow \mathrm{AXP} \longrightarrow \mathrm{MA} \longrightarrow \mathrm{V}$

Figure 5. Cumulative returns of networks sub-classification companies 
h. Payments

The performance of the payments companies is superior to KFTX and other indices over all the three time period at a risk relatively higher than the market portfolio indicating better performance of the FinTech companies in this sector.

Table 9. Analysis of payments sub-classification

\begin{tabular}{llrrr}
\hline Ticker & Component/Company Name & \multicolumn{3}{c}{ Returns } \\
\cline { 3 - 5 } & & 12 months & 24 months & 34 months \\
\hline Payments & & $24.5 \%$ & $63.1 \%$ & $71.6 \%$ \\
\multirow{2}{*}{ ACIW } & \multirow{2}{*}{ ACI Worldwide, Inc. } & $(1.17)$ & $(1.08)$ & $(1.20)$ \\
& & $19.1 \%$ & $29.7 \%$ & $45.7 \%$ \\
EVTC & Evertec, Inc. & $(1.65)$ & $(1.36)$ & $(1.34)$ \\
& & $9.4 \%$ & $36.1 \%$ & $57.1 \%$ \\
FIS & Fidelity National Information Services, & $(1.51)$ & $(1.01)$ & $(1.13)$ \\
& & $17.0 \%$ & $37.5 \%$ & $46.7 \%$ \\
FLT & FleetCor Technologies, Inc. & $(0.72)$ & $(0.77)$ & $(0.84)$ \\
& & $-0.8 \%$ & $37.1 \%$ & $59.3 \%$ \\
GDOT & Green Dot Corp. & $(1.50)$ & $(1.00)$ & $(1.02)$ \\
& & $51.2 \%$ & $123.0 \%$ & $69.8 \%$ \\
GPN & Global Payments, Inc. & $(0.94)$ & $(1.09)$ & $(1.41)$ \\
& & $17.9 \%$ & $43.4 \%$ & $66.1 \%$ \\
PYPL & PayPal Holdings, Inc. & $(1.22)$ & $(1.13)$ & $(1.21)$ \\
& & $41.5 \%$ & $81.8 \%$ & $105.8 \%$ \\
SQ & Square, Inc. & $(0.92)$ & $(1.12)$ & $(1.32)$ \\
& & $105.4 \%$ & $199.7 \%$ & $193.8 \%$ \\
TSS & Total System Services, Inc. & $(1.28)$ & $(1.62)$ & $(2.10)$ \\
& & $12.2 \%$ & $50.4 \%$ & $62.2 \%$ \\
WEX & Wex, Inc. & $(1.07)$ & $(0.97)$ & $(1.05)$ \\
& & $17.4 \%$ & $73.3 \%$ & $76.2 \%$ \\
WP & Worldpay, Inc. & $(1.33)$ & $(1.07)$ & $(1.16)$ \\
& & $6.7 \%$ & $38.5 \%$ & $71.1 \%$ \\
WU & The Western Union Co. & $(0.95)$ & $(0.85)$ & $(1.03)$ \\
& & $-2.7 \%$ & $7.1 \%$ & $5.5 \%$ \\
\hline
\end{tabular}




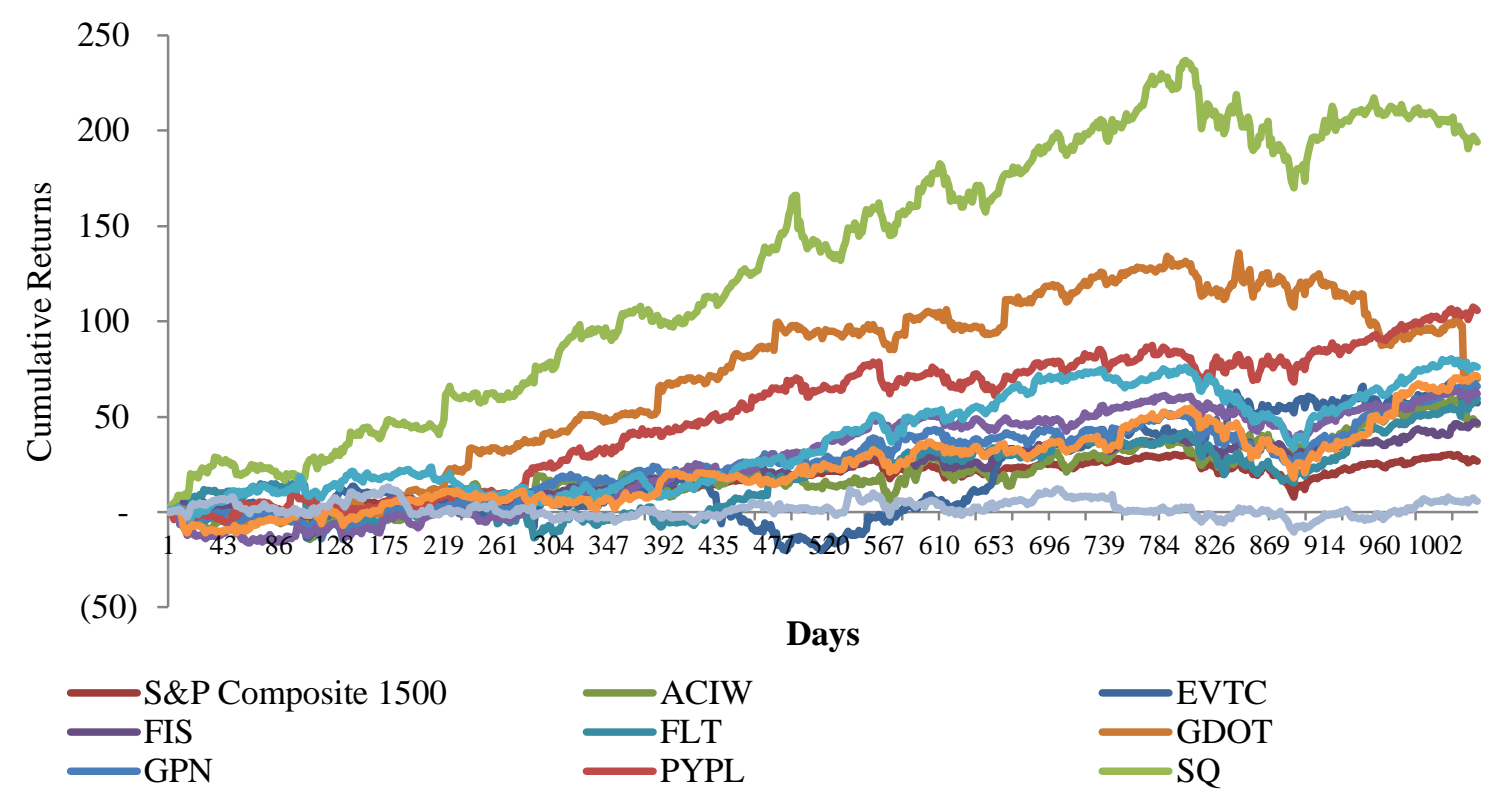

Figure 6. Cumulative returns of payments sub-classification companies

\section{i. Processors / Business Information}

The performance of the processors/business information companies is below the KFTX and at par with other indices over the 24 month and 34 month period at a risk comparable to the market portfolio. This signifies a better performance of these companies as compared to other sectors.

Table 10. Analysis of processors/business information sub-classification

\begin{tabular}{llrrr}
\hline Ticker & Component/Company Name & \multicolumn{3}{c}{ Returns } \\
\cline { 3 - 5 } Processors/Business Information & 12 months & 24 months & 34 months \\
& & $11.6 \%$ & $30.7 \%$ & $34.6 \%$ \\
ADS & Alliance Data Systems Corp. & $(0.99)$ & $(0.95)$ & $(1.03)$ \\
& & $24.5 \%$ & $9.8 \%$ & $-36.0 \%$ \\
BKI & Black Knight Financial Services, Inc. & $(1.43)$ & $(1.17)$ & $(1.24)$ \\
& & $9.1 \%$ & $36.9 \%$ & $37.3 \%$ \\
BR & Broadridge Financial Solutions, Inc. & $(0.74)$ & $(1.13)$ & $(1.01)$ \\
& & $13.2 \%$ & $60.7 \%$ & $65.3 \%$ \\
CATM & Cardtronics, Inc. & $(0.80)$ & $(0.86)$ & $(0.93)$ \\
& & $-30.1 \%$ & $-46.6 \%$ & $-26.3 \%$ \\
CLGX & CoreLogic, Inc. & $(0.90)$ & $(1.31)$ & $(1.50)$ \\
& & $8.2 \%$ & $30.9 \%$ & $0.9 \%$ \\
CSGP & Costar Group Inc & $(0.82)$ & $(0.80)$ & $(0.85)$ \\
& & $21.7 \%$ & $65.9 \%$ & $85.6 \%$ \\
EEFT & Euronet Worldwide, Inc. & $(1.24)$ & $(0.91)$ & $(1.00)$ \\
& & $22.3 \%$ & $18.5 \%$ & $75.6 \%$ \\
FISV & \multirow{2}{*}{ Fiserv, Inc. } & $(0.91)$ & $(0.88)$ & $(0.98)$ \\
& & $12.6 \%$ & $33.7 \%$ & $45.8 \%$ \\
JKHY & \multirow{2}{*}{ Jack Henry \& Associates, Inc. } & $(0.85)$ & $(0.79)$ & $(0.88)$ \\
& & $19.7 \%$ & $46.4 \%$ & $47.1 \%$ \\
SEIC & SEI Investments Co. & $(0.90)$ & $(0.80)$ & $(0.82)$ \\
& & $10.3 \%$ & $26.1 \%$ & $3.8 \%$ \\
SSNC & \multirow{2}{*}{ SS\&C Technologies Holdings, Inc. } & $(1.35)$ & $(1.10)$ & $(1.13)$ \\
VRSK & \multirow{2}{*}{ Verisk Analytics, Inc. } & $26.6 \%$ & $58.2 \%$ & $65.5 \%$ \\
& & $(1.21)$ & $(0.84)$ & $(1.15)$ \\
& & $0.9 \%$ & $27.9 \%$ & $50.9 \%$ \\
& & $(0.76)$ & $(0.79)$ & $(0.84)$ \\
\hline
\end{tabular}




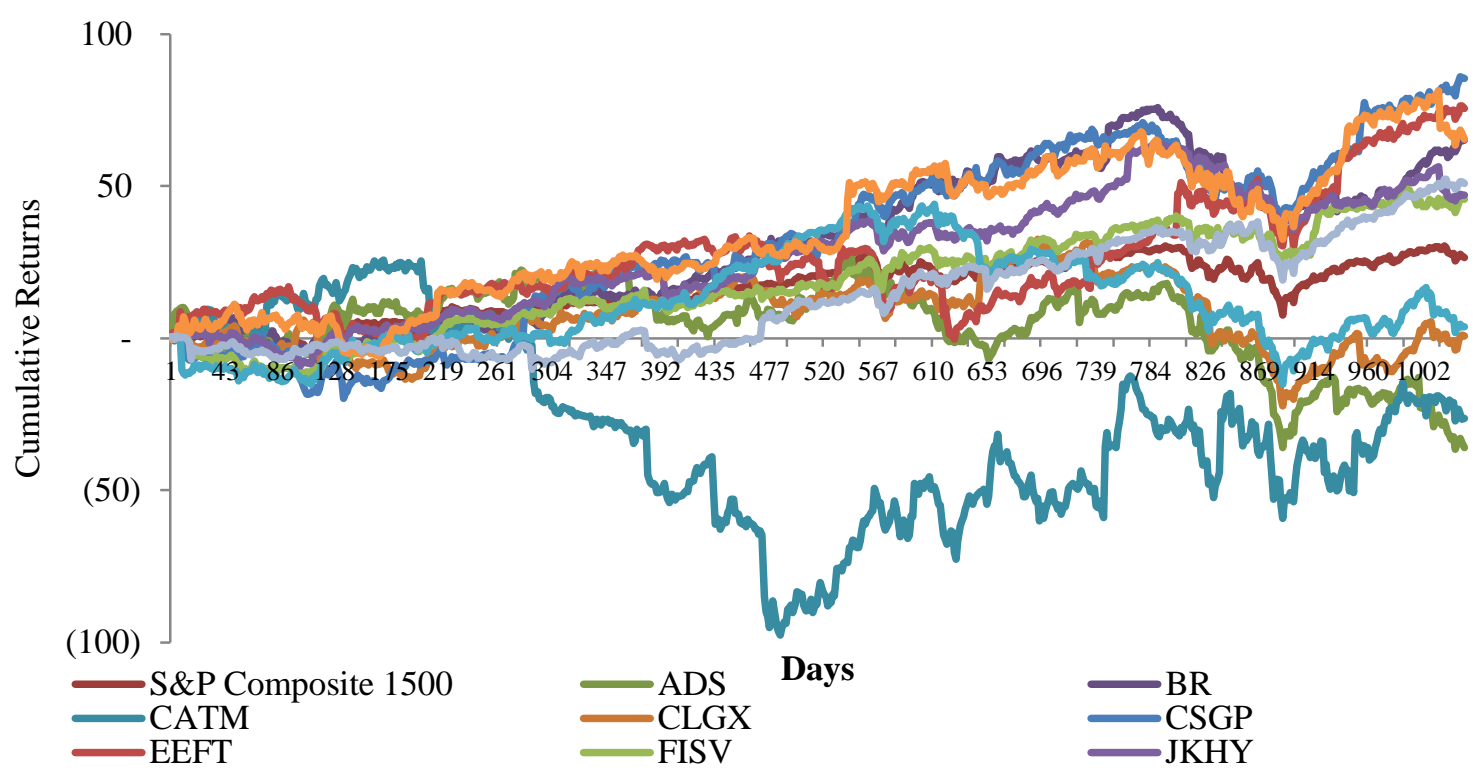

Figure 7. Cumulative returns of processors/business information sub-classification companies

\section{j. Software}

The performance of the software companies is below the KFTX and at par with other indices over the 24 month and 34 month period. However the company has a higher risk comparable to the market portfolio.

Table 11. Analysis of software sub-classification

\begin{tabular}{llrrr}
\hline Ticker & Component/Company Name & \multicolumn{3}{c}{ Returns } \\
\cline { 3 - 5 } & & 12 months & 24 months & 34 months \\
\hline \multirow{2}{*}{ Software } & & $4.3 \%$ & $45.4 \%$ & $59.3 \%$ \\
& & $(1.69)$ & $(1.20)$ & $(1.28)$ \\
ENV & \multirow{2}{*}{ Envestnet, Inc. } & $4.3 \%$ & $45.4 \%$ & $59.3 \%$ \\
& & $(1.69)$ & $(1.20)$ & $(1.28)$ \\
\hline
\end{tabular}

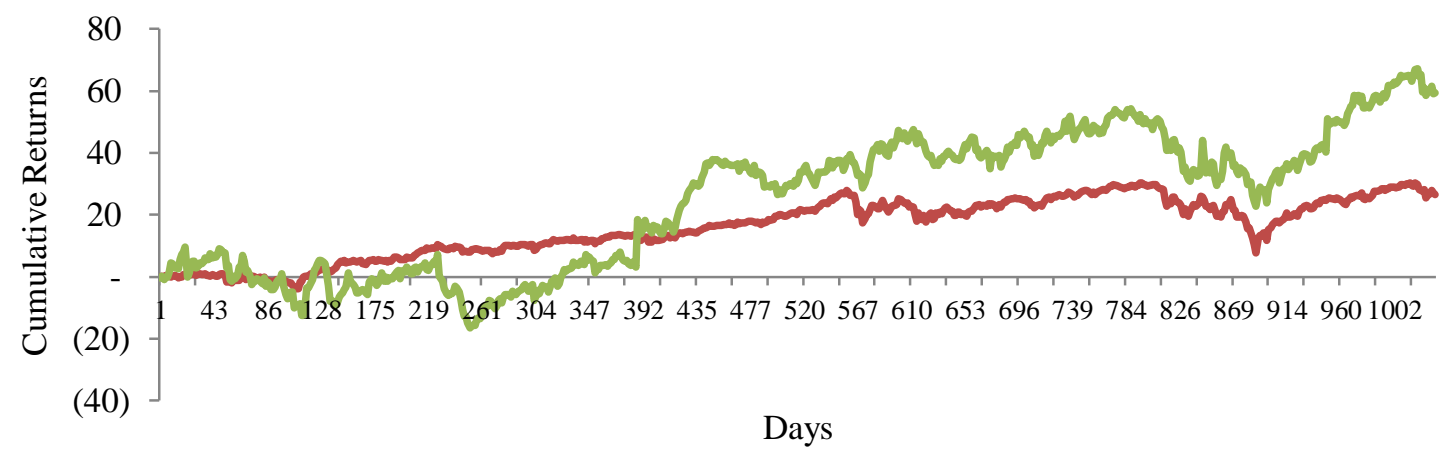

S\&P Composite $1500 \quad$ ENV

Figure 8. Cumulative returns of software sub-classification companies 


\section{k. $\quad$ Specialty Marketplace Lenders}

The performance of the specialty marketplace lender companies is below the KFTX and inferior to most all the three time periods at a risk higher than the market portfolio. This signifies that the business model of these companies is yet to be stabilised as compared other FinTech sectors.

Table 12. Analysis of specialty marketplace lenders sub-classification

\begin{tabular}{llrrr}
\hline Ticker & Component/Company Name & \multicolumn{3}{c}{ Returns } \\
\cline { 3 - 5 } & & 12 months & 24 months & 34 months \\
\hline Specialty & Marketplace Lenders & $16.6 \%$ & $40.6 \%$ & $26.6 \%$ \\
& & $(1.86)$ & $(1.23)$ & $(1.32)$ \\
LC & LendingClub Corp. & $14.0 \%$ & $-4.4 \%$ & $-35.0 \%$ \\
& & $(2.10)$ & $(1.20)$ & $(1.37)$ \\
\multirow{2}{*}{ ONDK } & \multirow{2}{*}{ On Deck Capital, Inc } & $-20.1 \%$ & $37.7 \%$ & $-17.5 \%$ \\
& & $(1.88)$ & $(1.27)$ & $(1.13)$ \\
TREE & Lendingtree, Inc. & $56.1 \%$ & $88.6 \%$ & $132.4 \%$ \\
& & $(1.70)$ & $(1.23)$ & $(1.49)$ \\
\hline
\end{tabular}

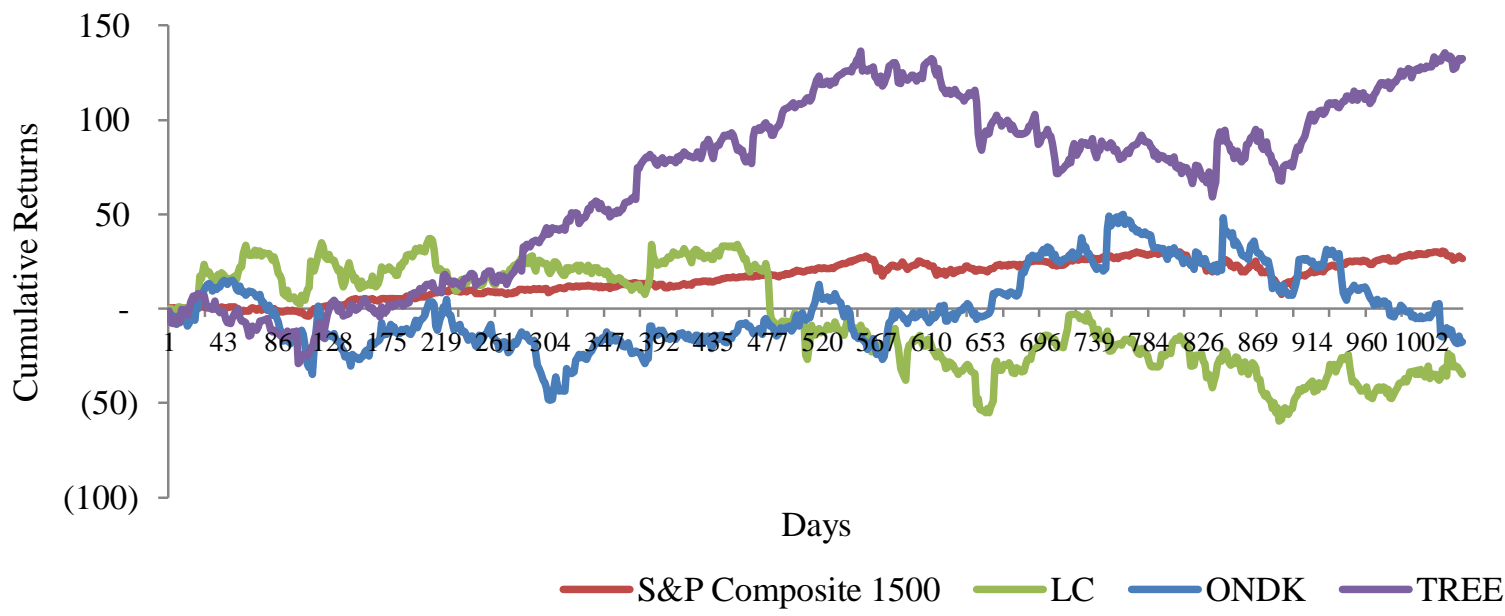

Figure 9. Cumulative returns of specialty market lenders sub-classification companies

As compared to the performance of KFTX index, cross section of the returns for various categories of the companies however presents a bit different picture. For the 34 months period asset management has produced return of negative - $51.0 \%$ and the specialty marketplace lenders have return of $26.6 \%$ and $34.6 \%$. This may be attributed to the fact that these business models are new and yet to garner sufficient conformity from the investor community.

At the same time networks and payments have returns of $82.1 \%$ and $71.6 \%$ respectively for the 34 months period. The rapid development of technology has resulted into increased access to cheap payment and settlement systems where traditional banking networks are scarce. The increased number of users and transaction frequency are driving the performance of these companies.

This indicates that the various sectors under the FinTech umbrella are not responding in the same way with the broad FinTech bandwagon. Sector specific analysis and commentary thus becomes essential while dealing with FinTech.

\section{Limitations}

The findings are limited by observing only 48 component companies of KFTX. As time progresses, the disruptive 
nature of FinTech is expected to give birth to more categories and companies in FinTech.

\section{Conclusion}

FinTech has caught the eye of the investor community and is expected to disrupt the financial services sector completely. Regulators are also keeping a close eye on the developments in the FinTech sector. Researchers attempt is to analyse the performance of the FinTech with respect to the broad industry and also the various sectors under the umbrella of FinTech.

The researchers have analysed the performance of the KBW Financial Technology Index post its inception till 2019 (analysed in three time periods of $12 \mathrm{~m}, 24 \mathrm{~m}$ and $34 \mathrm{~m}$ ) and compared it with the major indices. The findings indicate that the performance of KFTX index is way superior to other major indices such as S\&P 500 and DJI during the period of study. This can be attributed to heighten investor interest in FinTech companies.

Further, components of KFTX were broken into 9 sectors and a cross-section analysis was performed. The cross-section analysis indicates that there is no uniformity in the returns from various sub-sections under the FinTech. The sector specific performance observed during the period of study is as under:

Asset Management: It has given negative returns across all three time periods and has a very high beta indicating perceived high risk and nascent stage of the business model.

Exchanges/Automatic Trading: The superior performance and lower risk compared to market portfolio indicating higher interest from investors.

Financial Data: The superior performance and comparable risk to market portfolio indicating stabilised business models with increasing interest from investors.

Internet Banks: The superior performance and higher risk compared to market portfolio indicating new age business models with higher interest from investors

Networks: The superior performance with slightly higher risk indicating established business adapting to changing FinTech landscape.

Payments: The superior performance with slightly higher risk indicating business adapting to changing FinTech landscape.

Processors/Business Information: The low performance with risk comparable to market portfolio indicating the sector in not benefited by the increasing interests in FinTech.

Software: The low performance with high risk indicating nascent stage of the business model.

Specialty Marketplace Lenders: The low performance and high risk compared to market portfolio signifies that the business model of these companies is yet to be stabilised as compared other FinTech sectors

The rapid development of technology has resulted into increased access to cheap payment and settlement systems where traditional banking networks are scarce. The increased number of users and transaction frequency are driving the performance of networks and payments companies. The business models of asset management and specialty marketplace lenders are new and yet to garner sufficient conformity from the investor community.

Consumer centric payments and network companies have experienced high returns whereas lending, processors/business information and asset management have given lower returns. So policy makers and investors have to garner sector specific insights while dealing with FinTech companies.

\section{References}

Anagnostopoulos, I. (2018). Fintech and regtech: Impact on regulators and banks. Journal of Economics and Business, 100, 7-25. https://doi.org/10.1016/j.jeconbus.2018.07.003

Arner, D. W., Barberis, J. N., \& Buckley, R. P. (2015). The Evolution of Fintech: A New Post-Crisis Paradigm?. Geo. J. Int'l L., 47, 1271. https://doi.org/10.2139/ssrn.2676553

Bower, J. L., \& Christensen, C. M. (1995, January). Disruptive Technologies: Catching the Wave. Harvard Business Review, 73, 43-53. Retrieved from http://vedpuriswar.org/articles/Disruptivetechnologies-Catchingthewave.pdf

Brad, J. B. (2016). Future of Fintech in Capital Markets. Retrieved from http://deutsche-boerse.com/blob/2621702/ed055219caeb553f43950609d29e1bb3/data/future-of-fintech-in-capit al-markets_en.pdf

Dranev, Y., Frolova, K., \& Ochirova, E. (2019). The impact of fintech M\&amp;A on stock returns. Research in 
International Business and Finance, 48, 353-364. https://doi.org/10.1016/j.ribaf.2019.01.012

Drasch, B. J., Schweizer, A., \& Urbach, N. (2018, April). Integrating the 'Troublemakers': A taxonomy for cooperation between banks and fintechs. Journal of Economics and Business, 100, $26-42$. https://doi.org/10.1016/j.jeconbus.2018.04.002

EY. (2019). Global FinTech Adoption Index 2019. Retrieved from https://assets.ey.com/content/dam/ey-sites/ey-com/en_gl/topics/banking-and-capital-markets/ey-global-fintech-a doption-index.pdf

Fama, E. F., \& French, K. R. (2004). The Capital Asset Pricing Model: Theory and Evidence. The Journal of Economic Perspectives, $\quad 18(3), \quad$ 25-46. $\quad$ Retrieved from https://www.jstor.org/stable/pdf/3216805.pdf?refreqid=excelsior\%3A7863cb2441377dd0a9084e59ddaddc04

Feeney, G., \& Hester, D. (1964). Stock market indices: a principal components analysis. Cowles Foundation Discussion Papers. Retrieved from http://dido.econ.yale.edu/P/cd/d01b/d0175.pdf

Financial Stability Board. (2019). FinTech and market structure in financial services: Market developments and potential financial stability implications. https://www.fsb.org/2019/02/fintech-and-market-structure-in-financial-services-market-developments-and-pote ntial-financial-stability-implications/

Gomber, P., Kauffman, R. J., Parker, C., \& Weber, B. W. (2018). On the Fintech Revolution: Interpreting the Forces of Innovation, Disruption, and Transformation in Financial Services. Journal of Management Information Systems, 35(1), 220-265. https://doi.org/10.1080/07421222.2018.1440766

Gozman, D., Liebenau, J., \& Mangan, J. (2018). The Innovation Mechanisms of Fintech Start-ups: Insughts from Swifts’ Innotribe Competition. Journal of Management Information Systems, 35(1), 145-179.

Horrigan, H., Case, B., Geltner, D., \& Pollakowski, H. (2009). REIT-based property return indices: A new way to track and trade commercial real estate. Journal of Portfolio Management, 35(5). https://doi.org/10.3905/JPM.2009.35.5.080

Hsieh, H., \& Hodnett, K. (2013). A Review of Performance Evaluation Measures for Actively-Managed Portfolios. Journal of Economics and Behavioral Studies, 5(12), 815-824.

Jagtiani, J., \& Lemieux, C. (2018, April). Do fintech lenders penetrate areas that are underserved by traditional banks?. Journal of Economics and Business, 100, 43-54. https://doi.org/10.1016/j.jeconbus.2018.03.001

KBW. (2016a). Introducing the KBW Nasdaq Financial Technology Index. Retrieved from https://www.kbw.com/content/the-firm-PDFs/press-releases/KBW-KFTX_7.18.16.pdf

KBW. (2016b). KBW Nasdaq Financial Technology Index Methodology. Retrieved from https://indexes.nasdaqomx.com/docs/methodology_KFTX.pdf

KPMG. (2019a). Pulse of Fintech 2018. KPMG-Fintech-report. Retrieved from https://home.kpmg/xx/en/home/insights/2019/01/pulse-of-fintech-h2-2018.html

KPMG. (2019b). The Pulse of Fintech 2019 - Biannual global analysis of investment in fintech.

Lee, I., \& Shin, Y. J. (2018). Fintech: Ecosystem, business models, investment decisions, and challenges. Business Horizons, 61(1), 35-46. https://doi.org/10.1016/j.bushor.2017.09.003

Pollari, I. (2016). The rise of Fintech opportunities and challenges. The Journal of Applied Science in Southern Africa, 3(15). Retrieved from https://www.finsia.com/docs/default-source/jassa-new/JASSA-2016-/jassa-2016-issue-3/jassa-2016-iss-3-the-ris e-of-fintech-pp-15-21.pdf?sfvrsn=5f839b93_4

RBI. (2017). Report of the Working Group on FinTech and Digital Banking. Retrieved from https://rbidocs.rbi.org.in/rdocs/PublicationReport/Pdfs/WGFR68AA1890D7334D8F8F72CC2399A27F4A.PDF

Zhang, X., Tan, Y., Hu, Z., Wang, C., \& Wan, G. (2020). The Trickle-down Effect of Fintech Development: From the Perspective of Urbanization. China and World Economy, 28(1), 23-40. https://doi.org/10.1111/cwe.12310 


\section{Appendix A}

\section{KFTX Component Company Details}

\begin{tabular}{|c|c|c|}
\hline $\begin{array}{l}\text { Sr. } \\
\text { No. }\end{array}$ & Ticker & Company Name \\
\hline \multicolumn{3}{|c|}{ I. Asset Management } \\
\hline 1 & WETF & $\begin{array}{l}\text { WisdomTree Investments, } \\
\text { Inc }\end{array}$ \\
\hline \multicolumn{3}{|c|}{ II. Exchanges / Automatic Trading } \\
\hline 2 & CBOE & CBOE Holdings, Inc. \\
\hline 3 & CME & CME Group, Inc. \\
\hline 4 & ICE & $\begin{array}{l}\text { Intercontinental Exchange, } \\
\text { Inc. }\end{array}$ \\
\hline 5 & MKTX & MarketAxess Holdings, Inc \\
\hline 6 & NDAQ & Nasdaq, Inc. \\
\hline 7 & VIRT & Virtu Financial, Inc. \\
\hline
\end{tabular}

\section{Financial Data}

8 EFX Equifax, Inc.

\section{Business}

The group operates as an asset manager and ETFs sponsor and provides investment advisory services.

The group operates a financial options trading platform.

The group operates a derivatives exchange.

The company operates a global commodity and financial products marketplaces.

It operates an electronic, multi-dealer to client platform for bond trading.

It operates as a stock exchange.

The group provides market making and liquidity services through its proprietary, multi-asset, and multi-currency technology platform to the financial markets

It provides information solutions such as credit information and credit scoring, credit modeling and portfolio analytics; financial marketing; and identity management services.

9 FDS FactSet Research Systems Inc.

It provides global economic and financial data to financial community.

10 FICO Fair Isaac Corp.

$\begin{array}{lll}11 & \text { INFO } & \text { IHS Markit Ltd. } \\ 12 & \text { MCO } & \text { Moody's Corp. } \\ 13 & \text { MSCI } & \text { MSCI, Inc. } \\ 14 & \text { SPGI } & \text { S\&P Global, Inc. } \\ 15 & \text { TRI } & \text { Thomson Reuters Corp. }\end{array}$

It provides analytics, including predictive modeling, decision analysis, intelligence management, decision management systems, and consulting services.

It provides critical information, analytics and solutions to businesses and government.

It is a credit rating, research and risk analysis firm.

It provides decision support tools; produces indices and risk and return portfolio analytics.

It provides information regarding ratings, benchmarks and analytics.

The Company provides proprietary online systems in information sectors such as legal and regulatory, financial, scientific reference and healthcare, and corporate training.

16 TRU Transunion

It operates as a credit reporting agency.

IV. Internet Banks

17 AX Axos Financial, Inc.

The group provides consumer and business banking products.

V. Networks

18 AXP American Express Co. It is a global payment and travel company.

19 MA MasterCard, Inc. It offers payment processing services. 


$20 \quad$ V Visa, Inc.

\section{Payments}

21 ACIW

22 EVTC Evertec, Inc.

$23 \quad$ FIS

$24 \quad$ FLT

\section{GDOT}

Green Dot Corp.

26 GPN Global Payments, Inc.

27 PYPL PayPal Holdings, Inc.

28

29 TSS

30 WEX

Square, Inc.

Total System Services, Inc.

31 WP Worldpay, Inc.

32 WU The Western Union Co.

\section{Processors / Business Information}

33 ADS

$34 \quad$ BKI

EEFT

Euronet Worldwide, Inc.

40 FISV Fiserv, Inc.
It operates a retail electronic payment network and manages global financial services.

It provides software products for the global electronic funds transfer market.

It offers merchant acquiring, payment processing and business process management services.

It is a payment services provider.

It is a payment services provider to commercial fleets, oil companies and petroleum markets.

It provides prepaid debit card products, prepaid card reloading services and mobile banking products.

It provides payment technology and software solutions for card, electronic, check, and digital-based payments

It operates a technology platform that enables digital and mobile payments.

It provides mobile payment solutions, pos software and analytics.

It provided electronic payment processing and related services.

It provides payment processing and information management services.

It operates as an online payments processing company and offers proprietary technology platforms.

It provided global money transfer services.

It provides data-driven and transaction-based marketing and customer loyalty solutions.

The group provides integrated technology, work flow automation, data, and analytic solutions to the mortgage and real estate industries.

It provides technology-based outsourcing solutions to the financial services industries

It provides automated consumer financial services through its network of ATMs and multi-function financial services kiosks

It provides consumer, financial and property information, analytics and services to business and government.

It provides information, analytics, and online marketplaces to the commercial real estate industry

It offers financial payment middleware, financial network gateways, outsourcing, and consulting services to financial institutions and mobile operators.

It provides integrated information management and electronic commerce systems and services.

It provides integrated computer systems for data processing to banks and other FIs. 


\begin{tabular}{|c|c|c|c|}
\hline 42 & SEIC & SEI Investments Co. & $\begin{array}{l}\text { It provides global investment and business solutions to banks and } \\
\text { other FIs }\end{array}$ \\
\hline 43 & SSNC & $\begin{array}{l}\text { SS\&C Technologies } \\
\text { Holdings, Inc. }\end{array}$ & $\begin{array}{l}\text { It provides software that enables trading and modeling, portfolio } \\
\text { management and reporting, accounting, performance measureme } \\
\text { etc. }\end{array}$ \\
\hline 44 & VRSK & Verisk Analytics, Inc. & It provides risk assessment services and decision analytics. \\
\hline \multicolumn{4}{|c|}{ VIII. Software } \\
\hline 45 & ENV & Envestnet, Inc. & $\begin{array}{l}\text { It develops and markets computer software for financial } \\
\text { advisors }\end{array}$ \\
\hline \multicolumn{4}{|c|}{ IX. Specialty Marketplace Lenders } \\
\hline 46 & $\mathrm{LC}$ & LendingClub Corp. & $\begin{array}{l}\text { It operates online lending marketplace platform that connects } \\
\text { borrowers and investors for consumer and small business } \\
\text { loans. }\end{array}$ \\
\hline 47 & ONDK & On Deck Capital, Inc. & It operates online platform for small business lending. \\
\hline 48 & TREE & Lendingtree, Inc. & $\begin{array}{l}\text { It operates an online lending marketplace for real estate, } \\
\text { consumer and student loans. }\end{array}$ \\
\hline
\end{tabular}

\section{Copyrights}

Copyright for this article is retained by the author(s), with first publication rights granted to the journal.

This is an open-access article distributed under the terms and conditions of the Creative Commons Attribution license (http://creativecommons.org/licenses/by/4.0/). 